\title{
The Change of Secondary School Students' Environmental Consciousness, Attitude and Behaviors with Nature Education Project
}

\author{
Serkan Sevim ${ }^{1}$ \\ ${ }^{1}$ Pamukkale University, Education Faculty, Denizli, Turkey \\ Correspondence: Serkan Sevim, Pamukkale University, Education Faculty, Denizli, Turkey. \\ Tel: 90-533-232-0355. E-mail: serkansvm@yahoo.com
}

Received: February 28, 2020

Accepted: March 10, 2020 Online Published: March 18, 2020

doi:10.5539/hes.v10n2p82

URL: https://doi.org/10.5539/hes.v10n2p82

\begin{abstract}
The purpose of this study is to determine the effect of the nature education project on the attitudes and awareness levels of secondary school students towards the environment. The research is based on an experimental model which is a type quantitative research approaches and the population consisting of the students studying at a secondary school in Denizli. The sample of the study consists of 24 students participating in the project selected from Denizli. The first criterion for the selection of the students was determined as the participation of a 4006 science fair before, and other criteria were some variables such as academic achievement, gender, absence of health problems, and high communication skills. The data of the study collected with the journal form was used to gather the opinions and thoughts of the participants through an "Environmental Affect Scale" (EAS) consisting of 15 questions in type of five point likert scale along with another "Environmental Behavior Scale" (EBS) consists of 12 questions in type of seven point likert scale that were both developed by Sontay, Gökdere \& Usta (2014). SPSS 22 program is used in the analysis of the data. When the results obtained are evaluated in general, it is evident that nature education program significantly contributes to both the environmental consciousness and environmental attitudes of the participants. In addition, in the evaluation made according to the sub-dimensions of the attitude scale, it is clearly seen that the program increases students' positive attitudes towards the environment as well as ensuring their permanence. However, no significant differences were found in the environmental perception scores of the students.
\end{abstract}

Keywords: nature education project, secondary school students, the attitudes and awareness levels towards the environment

\section{Introduction}

The fastest learning for children occurs when they use their senses. The nature that offers such a learning environment serves almost as a laboratory (Akköse, 2008; Aslan, Sağır \& Cansaran, 2008; Erentay \& Erdoğan, 2012; Birinci, 2013). Nature education enables students to make research in this laboratory and discover information in this way. Thanks to the trainings, it is aimed to raise individuals who are conscious of nature. Thus, it is aimed for individuals to develop positive attitudes towards nature and turn these attitudes into behaviors while also transferring ecological information with nature trainings (Şimşekli, 2004; Özdemir, 2007; Özdemir, Akfirat, \& Adıgüzel, 2009). In addition, these trainings address the cognitive, affective and psycho-motor learning areas of the students (Erten, 2004), give them critical thinking (Korfiatis, 2005), problem solving and effective decision making skills (Cited from: Knapp \& Poff, 2001; Çelebi, 2002; Özdemir, 2010; Erdoğan, 2011; Dilli, 2015).

According to Bruner, the individual who has curiosity and desire to learn enters the learning life with intrinsic motivation in learning by exploring and thus learning becomes much more permanent. Therefore, nature education is an effective way to gain knowledge, attitudes, skills and behaviors related to nature. In this respect, nature education can be used to teach how humans affect nature, how they are affected by nature, and can give feelings of love and value towards nature (Bullock, 1994; Kırıkoğlu, 2004; Çukur \&Özgüner, 2008; Okur-Berberoğlu \& Uygun, 2013). However, research results (Atasoy, 2005; Tanesen, 2008; Tanrırdi, 2009; Kahyaoğlu, 2015; Kahyaoğlu\&Yetişir, 2015) indicate that children do not realize the processes in nature, that they cannot see the diversity of plants and animals, that they do not know how this diversity can be beneficial to nature, that they cannot perceive many more details about nature such as what causes the number of plants and 
animals to be more or less, that they have misconceptions about the elements in nature, especially the concepts of plant and living things (Stavy \& Wax, 1989; Türkmen et al., 2003; Atasoy, 2005; Tanesen, 2008; Tanrırdi, 2009; Kahyaoğlu, 2015; Kahyaoğlu\&Yetişir, 2015). As a result, there is a great need to carry out studies aimed at helping students recognize the nature.

According to Albert Einstein, "Imagination is more important than knowledge". Focusing on one sided education (mathematics, science, etc.) in the development of the child may lead to immediate successes but also creates deficiencies that cannot be compensated for in the future. Regardless of which profession children are directed to, the individuals who have grown up with art education appropriate for their purpose and whose aesthetic appreciation has developed will contribute more to themselves and their societies (Buyurgan\&Buyurgan, 2012). In this respect, art education enables individuals and society to be sensitive to the environment in which they live, mainly through artistic activities. It enables them to enter into a beneficial interaction with their environment, meet their aesthetic needs, produce products and feed their interpretive motives, make their lives more meaningful and constitutes the most reliable environment including the development of students in a broad sense. Because, in this environment, students can apply their natural tendencies and use their own experiences in parallel with their own pace.

In this context, it has been stated that nature education, which allows to get to know nature in natural environments, will directly affect students' recognition of nature by presenting the real life equivalent of knowledge through field trips and practical activities used in these trips (Keleş, Uzun \& VarnacıUzun, 2010; Karataş, 2011; Erentay \& Erdoğan, 2012). Similarly, in a study conducted by Güneş et al. (2011), when the teachers were asked how to overcome the deficiencies in science and nature related issues in connection with the new curriculum, the participants stated that the field trip and observation studies would be the most beneficial. In a study conducted by Willis (2001) on the teachers who conduct nature studies in their environment, teachers state that their students learn by having fun in nature studies. Moreover, it is seen that the participants stated that they learned by having a lot of fun during nature studies carried out in our country (Yardımc1, 2009; Feyzioğlu et al., 2012). It has been revealed by various studies that nature education enables individuals to be informed about natural processes even if they are short term, and makes them more sensitive and conscious (Ozaner, 2004). This situation reveals the role of nature education in raising the "awareness of nature responsibility" which is frequently targeted in today's nature curricula. The fact that nature education has these features is an important advantage in terms of teaching activities. As a result of the investigations made in this context, it can be said that nature education based on the learning of nature as a whole and in terms of living and inanimate elements is very important due to increasing the connection between nature and the individual, its being an effective way because it includes active learning experiences, its being enjoyable and interesting in terms of learning activities.

Neither parents nor teachers can fully have students comprehend that every living and inanimate element on our planet, every plant and animal in ecosystems has a duty and function in terms of natural balance, and that the interaction between living and inanimate elements in nature is inevitable. Since the functionality and importance of the elements in nature are viewed from the benefit-harm, useful-useless and important-insignificant perspective of the adults, there are great obstacles in making children comprehend the unity of nature, that all parts are inseparable and important elements of this great whole, that the biosphere is not a machine, but a living, changing, developing but orderly and organized system. It is a fact that the child, who cannot comprehend the function and importance of ecosystem and biosphere, and the order and integrity within it, cannot comprehend the fact of nature and the importance of the environment (Atasoy, 2005). For this reason, children should be expected to behave responsibly towards their environment by providing them with proper nature education. In the studies conducted to determine the children's perception of nature, it was revealed that the first thing that comes to mind in nature is living things, that they talk more about plants and animals and that they see plants as a more basic element (Bonnet \& Williams, 2006; Yardımc1, 2009; Burgess \& Smith, 2011; Köşker, 2013).

In the light of the above, a nature education project has been prepared and implemented. The project was supported by The Scientific and Technological Research Council of Turkey (TÜBITAK). TUBITAK briefly, to promote science and technology in Turkey, orientation and aims to popularize Science, Industry and Technology Ministry's "relevant" is one of the institutions subject to special legal provisions. Each year, the project is supported by different programs in many different titles. One of these programs is 4004 Nature Education and Science Schools Support Program. 4004 Nature Education and Science Schools Support Program; it can be expanded and brought together with the society, by visualizing that information is possible, and in an understandable way with interactive applications. In the projects within the scope of the program; It is aimed to encourage the participants' scientific facts, research, inquiry and learning requests. This project has been supported in this context. 
The focus of the project was determined as "plants" and "animals". However, in addition to these two basic elements, archaeology and astronomy were included in the project. The main goal of the project is to ensure that participants can feel their importance in nature and life for ten days, develop experiments, observation materials, apply their studies on site, and see the species selected for events in their habitats. As an implicit gain, it is aimed to meet the holiday needs by spending time with friends, by taking advantage of peer education opportunities and by team work. The selected region is Dalyan, a suitable area for the activities. The region in the Southern Tourism Region has an important position in terms of ecotourism due to its natural beauties, historical values and rapidly developing tourism potential. Dalyan, one of the rare places that could protect its natural beauty in the Muğla region, also has a great potential in terms of scientific use and ecotourism. This region is very rich in terms of endemic plant diversity. At the same time, Carettacaretta turtles have natural habitats and spawning areas. Ekincik, Dalyan, Dalaman, Fethiye, Patara, Kale, Kumluca, Tekirova, Belek, Kızılot, Gazipaşa, Demirtaş, Anamur, Göksu Delta, Kazanlı, Akyatan, Samandağ, Çıralı, Alata and Yumurtalik belonging to Carettacaretta and Cheloniamydas There are 20 nesting beaches (Lutz \&Musick, 1997; Kaska et al. 2001; Türkozan and Kaska 2010). They Dalyan beach is a beach where the sea turtle conservation efforts began in Turkey. In addition to the Dalyan beach is an area where urea sea turtles have been declared the best open protected areas in Europe in 2008 and also called DEKAMER on the beach, Turkey's first Sea Turtle Research Rescue and Rehabilitation Center (dekamer.org.t) was founded. Dalyan beach and DEKAMER de protection work every year with the participation of volunteers from various universities in Turkey and the world are carried out. In this project, the existing natural, cultural and historical values of Dalyan are the basic elements of the education prepared. In this way, the biodiversity, historical and social structure of Dalyan are provided with a popular language and the perceptions of the participants who attend the training by using active learning methods and techniques. Within the scope of this project, it is aimed that the participants see the relevant works in place and create awareness in terms of protecting the biodiversity of the country and creating awareness of nature conservation. Not only the theoretical courses but also the applications were included in the planning of the activities. The balance between theory and practice is considered in all topics.

In this respect, the general purpose of our project is to contribute to the training of individuals who have basic knowledge about the functioning of nature through plants, are sensitive to nature and nature problems, have developed a positive attitude towards nature, can use scientific process skills and creativity, integrate what nature has to offer to art, and can evaluate interdisciplinary interactions between arts and basic sciences.

\section{Method}

\subsection{Method}

This research was carried out with 24 students studying in secondary school on the 8th grade in the summer term of 2018-2019 academic year. Experimental method was used in this research. The "pretest-posttest single-group pattern" of this method constitutes the research model. In the single group pretest-posttest model, an independent variable is applied to a group and the scores were measured before and after the application. In the model, the application is considered to be effective only if the arithmetic means of the group's pretest scores obtained from the measurement tool differ significantly from the arithmetic means of the posttest points (Karasar, 2002; Balc1, 2004).

\subsection{Population and Sample}

After having TÜBİTAK support financially for the project, the announcement posters were sent to the project e-mail group and secondary schools in Denizli. Students applied for the project online via the project's website by filling in the form and the participants were selected from 158 secondary school students. The first criterion for the selection of the students was determined as the participation of a 4006 science fair before, and other criteria were some variables such as academic achievement, gender, absence of health problems, and high communication skills. 24 students were determined in such a way that the gender distribution was as equal as possible.

\subsection{Data Collection Tools and Analyses of the Data}

The data of the study collected with the journal form was used to gather the opinions and thoughts of the participants through an "Environmental Affect Scale" (EAS) consisting of 15 questions in type of five point likert scale along with another "Environmental Behavior Scale" (EBS) consists of 12 questions in type of seven point likert scale which were both developed by Sontay, Gökdere \& Usta (2014). The Environmental Affect Scale consists of 15 items prepared as a 5-point Likert type which includes the environmental characteristics of secondary school students. Students are expected to mark the extent to which they agree with the written statements. The Cronbach's alpha reliability of EAS was found to be 0.860 . As a result of the exploratory factor 
analysis, EAS was found to have a 3-factor structure. The items in each factor were examined and named as environmental responsibility, environmental sensitivity and environmental perception in accordance with the "affective domain" component.

The Environmental Behavior Scale consists of 12 items prepared as a 7-point Likert type that includes the positive behaviors of the students towards the environment. Students are expected to mark the number of times they have done the statements so far. The Cronbach's alpha reliability of EBS was found to be 0.773 . As a result of the exploratory factor analysis, EBS was found to have a 3-factor structure. By examining the items in each factor, the factors that were in accordance with the "behavior" component were named as "protective behavior of natural balance", "social behavior" and "high level cognitive behavior".

In addition, the journal form was used to collect the opinions and thoughts of the participants for each day in the project process. This form consists of two parts. The first part tries to identify the emotional change process created by the project process in the students. In this context, the students were asked to express their opinions on the activities and how their three different senses (......I got excited,...... got happy,....I got bored) changed, and to explain their reasons. In the second part, the students were asked open-ended questions consisting of six questions and asked to give their opinions in writing.

While the Environmental Affect Scale scores were calculated, an environmental awareness score for each student was calculated by giving values between 5 (strongly agree) and 1 (strongly disagree) according to the answers. While calculating the Environmental Behavior Scale scores, values ranging from 7 (fully agree / always) to 1 (never agree / never) were given and an environmental behavior score for each student was obtained. SPSS 20 package program was used in the analysis of the data obtained from the preferred measurement tool within the scope of the research. The Wilcoxon signed-ranks test was used because of variance homogeneity and limited sample size for each factor in the measuring tool. It is designed for repeated measurements of non-parametric tests. It is used when participants are evaluated under two situations or when evaluated under two different situations. The purpose here is not to make comparisons over the average scores of individuals, as in parametric tests. Wilcoxon turns points into rows and compares them with variables.

\section{Findings}

In this section, the findings of The Environmental Affect Scale and The Environmental Behavior Scale applied to determine the attitudes and awareness of the participants before and after the project and the data obtained from the journal form written by the participants during the project are included. The items in each factor in the Environmental Affect Scale were examined and presented below.

\subsection{Findings Obtained From The Environmental Affect Scale}

The Environmental Affect Scale have a 3-factor structure. The impact of the activities carried out within the scope of the project on the first factor (environmental responsibility) of the scale was examined and the findings obtained are presented in Table 1.

Table 1. The effect of project activities on the first factor of the scale

\begin{tabular}{llllll}
\hline Posttest - Pretest & N & Mean Rank & Rank Total & Z & p \\
\hline Negative Rank & 3 & 4.50 & 13.50 & -2.863 & 0.004 \\
Positive Rank & 13 & 9.42 & 122.50 & & \\
Equal & 8 & & & & \\
Total & 24 & & & & \\
\hline
\end{tabular}

$(\mathrm{p}<, 05$ is significant level)

When Table 1 was examined, it was found that there was a significant difference between the pretest and posttest scores of the students for the first factor of the questionnaire $(\mathrm{Z}=-2.863, \mathrm{p}<0.05)$. It is seen that this difference is in favor of the posttest. This result reveals that project activities are effective for students' development, learning and individual approaches towards environment.

The effect of project activities on on the second factor (environmental sensitivity) of the questionnaire was examined and the findings obtained are shown in Table 2. 
Table 2. The effect of project activities on the second factor of the scale

\begin{tabular}{llllll}
\hline Posttest - Pretest & N & Mean Rank & Rank Sum & Z & p \\
\hline Negative Rank & 0 & 0.00 & 0.00 & -3.928 & 0.000 \\
Positive Rank & 20 & 1.50 & 210.00 & & \\
Equal & 4 & & & & \\
Total & 24 & & & & \\
\hline
\end{tabular}

$(\mathrm{p}<, 05$ is significant level)

When Table 2 was examined, it was found that there was a significant difference between the pretest and posttest scores of the students for the second factor of the questionnaire $(Z=-3.928, p<0.05)$. It is seen that this difference is in favor of the posttest. This result reveals that the environmental sensitivity of the students increased with project activities.

The effect of project activities on the third factor (environmental perception) of the scale was examined and the findings obtained are presented in Table 3.

Table 3. The effect of project activities on the third factor of the scale

\begin{tabular}{llllll}
\hline Posttest - Pretest & N & Mean Rank & Rank Sum & Z & p \\
\hline Negative Rank & 2 & 11.00 & 22.00 & -1.402 & 0.161 \\
Positive Rank & 10 & 5.60 & 56.00 & & \\
Equal & 12 & & & & \\
Total & 24 & & & & \\
\hline
\end{tabular}

$(\mathrm{p}<, 05$ is significant level)

According to Table 3, there was no significant difference between the pretest and posttest scores of the students for the third factor $(Z=-1.402, p>0.05)$. This result shows that the activities carried out within the scope of the project are not effective on the students' perception of the environment.

\subsection{Findings Obtained From The Environmental Behavior Scale}

The Environmental Behavior Scale consists of 12 items prepared as a 7-point Likert type that includes the positive behaviors of the students towards the environment. The data obtained from the scale is presented below.

The effects of the activities carried out within the scope of the project on the first factor of the scale (natural balance-protective behavior) were examined and the findings obtained are presented in Table 4.

Table 4. The effect of project activities on the first factor of the scale

\begin{tabular}{llllll}
\hline Posttest - Pretest & N & Mean Rank & Rank Total & Z & p \\
\hline Negative Rank & 0 & 0.00 & 0.00 & -3.742 & 0.000 \\
Positive Rank & 18 & 9.50 & 171.00 & & \\
Equal & 6 & & & & \\
Total & 24 & & & & \\
\hline
\end{tabular}

$(\mathrm{p}<, 05$ is significant level)

When Table 4 was examined, it was found that there was a significant difference between the pretest and posttest scores of the students for the first factor of the questionnaire $(Z=-3.742, p<0.05)$. It is seen that this difference is in favor of the posttest. This result shows that project activities have a positive effect on students' protective behavior of natural balance.

The effect of the project activities on the second factor (social behavior) of the scale was examined and the findings obtained are presented in Table 5.

Table 5. The effect of project activities on the second factor of the scale

\begin{tabular}{llllll}
\hline Posttest - Pretest & N & Mean Rank & Rank Sum & Z & p \\
\hline Negative Rank & 1 & 5.50 & 5.50 & -3.939 & 0.000 \\
Positive Rank & 21 & 11.79 & 247.50 & & \\
Equal & 2 & & & & \\
Total & 24 & & & & \\
\hline
\end{tabular}


$(\mathrm{p}<, 05$ is significant level)

When Table 5 was examined, it was found that there was a significant difference between the pretest and posttest scores of the students for the second factor of the scale $(Z=-3.939, p<0.05)$. It is seen that this difference is in favor of the posttest. This result reveals that students' thoughts about social behavior have improved positively through project activities.

The effect of the project activities on the third factor (high level cognitive behavior) was examined and the findings were presented in Table 6.

Table 6. The effect of project activities on the third factor of the scale

\begin{tabular}{llllll}
\hline Posttest - Pretest & N & Mean Rank & Rank Sum & Z & p \\
\hline Negative Rank & 0 & 0.00 & 0.00 & -4.288 & 0.000 \\
Positive Rank & 24 & 12.50 & 300.00 & & \\
Equal & 0 & & & & \\
Total & 24 & & & & \\
\hline
\end{tabular}

$(\mathrm{p}<, 05$ is significant level)

When Table 6 was examined, it was found that there was a significant difference between the pretest and posttest scores of the students for the third factor of the scale $(\mathrm{Z}=-4.288, \mathrm{p}<0.05)$. It is seen that this difference is in favor of the posttest. This result reveals that students' thoughts about social behavior have improved positively through project activities.

\subsection{Findings Obtained From Journals}

Reflections of the students' emotional states during the project process were obtained via journals and the following findings were reached after the analysis of the data obtained.

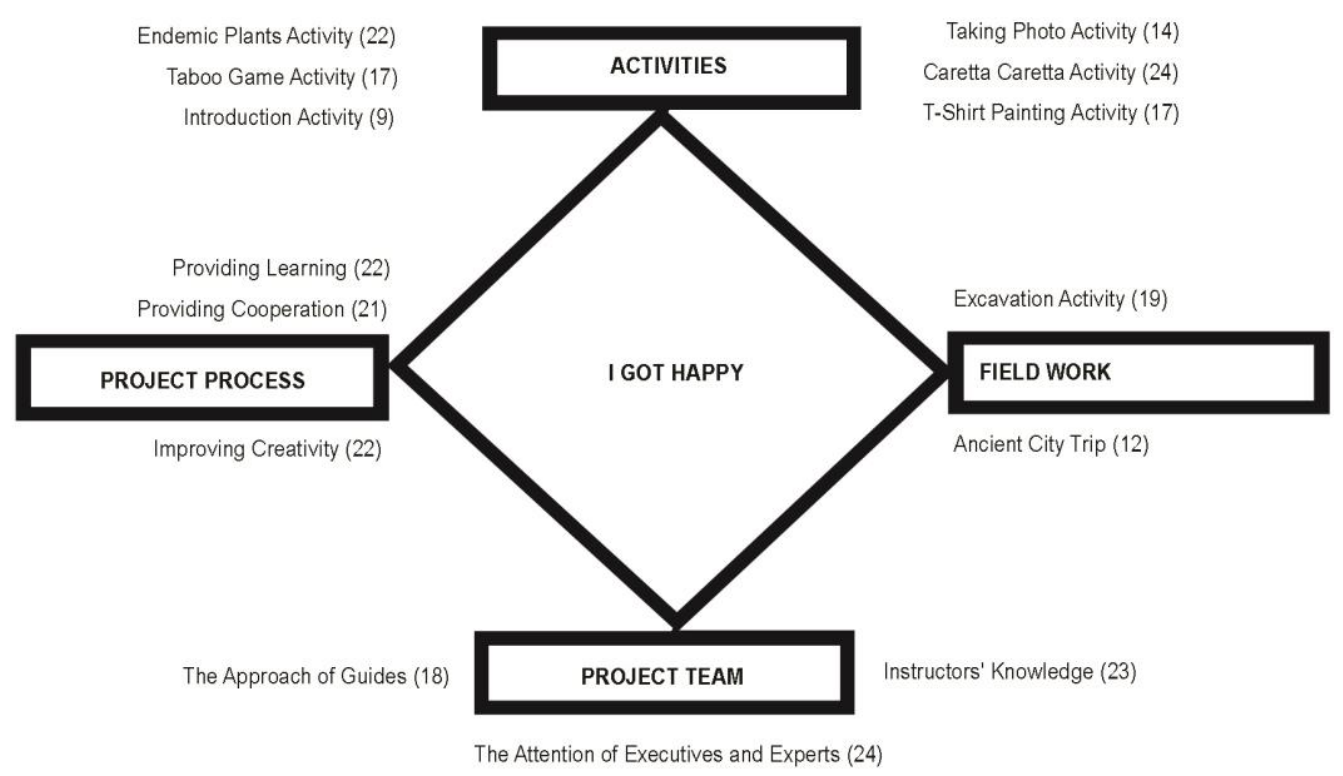

Figure 1. Participant Opinions on the State of Emotion "I Got Happy"

When Figure 1 is examined, sub-concepts and frequencies related to the theme "I got happy", which is one of the participants' state of emotions in the project process, are seen. The theme "I got happy" is divided into four main topics, which are activities, field work, project team and project process. 
When the participants stated that they were happy about the activities during the project, it was seen that the Caettacaretta activity was intensively mentioned. The participant K21 has expressed his/her opinion on the subject saying: "I thought the sea-covered turtles lived far from humans. However, I learned that they lived with us. Thanks to the activities in this project, we got a lot of information. Thanks to this project, I learned that they are so affected by people and environmental pollution.", while the participant K09 said, "I was very happy that I actively participated in the sea turtle event and treated the injured animal for the first time, helping the turtles to reach the sea. It was a very important issue for me to have the chance to experience that there are many things that can be done for the plants and animals around me. I would like to participate in such applications constantly from now on.". The participant K13 commented, "Before I joined the project, I thought that many things I did in my daily life were innocent things. During the nature trips and sea turtles conservation center visits in the project, I realized how wrong we actually were. For example, I learned that fishing is actually caused by the death of many turtles when not done properly."

When we look at the participants who stated that they were happy with the project team during the project process, the approach of guides title was seen to be mentioned intensively. On the topic, the participant K01 said, "I am very happy with the interest of the project team and the guides, who are always in the background in the project or during an activity but who in fact deals with all kinds of our problems. I owe them a debt of gratitude", while the participant K04 stated, "From the day we arrived until the departure from the project center, I was very pleased with our guides who were always with us from activities to meals and I was very happy to meet them". The participant K17 commented, "I would like to thank the project team and the guides for their active role in the activities and the communication of the team with each other. Their attitude has been my source of happiness since I was involved in a project for the first time".

When we look at the participants who stated that they were happy because of the project process, it was seen that the title of enabling cooperation was intensely mentioned. The participant K12 has expressed his or her opinion on the subject saying, "It was good to have group friends during the activity and to help me with any problems that might occur. I was happy that we cooperated to solve the problems", while the participant K22 said, "I was usually working alone at school. In the project, our teachers constantly asked us to work with our group of friends. When I worked this way, I realized that I learned better. Thanks to my friends, I learned that I had misbehaved before. I believe that I will do more correct things now. I made new friends and I would like to work with them during the school period as I will take the same lessons with them all." And, the participant K15 commented, "I was happy to have collaborated with my group friends in the activities. Everybody contributed by doing a different job so we could get more efficiency in less time."

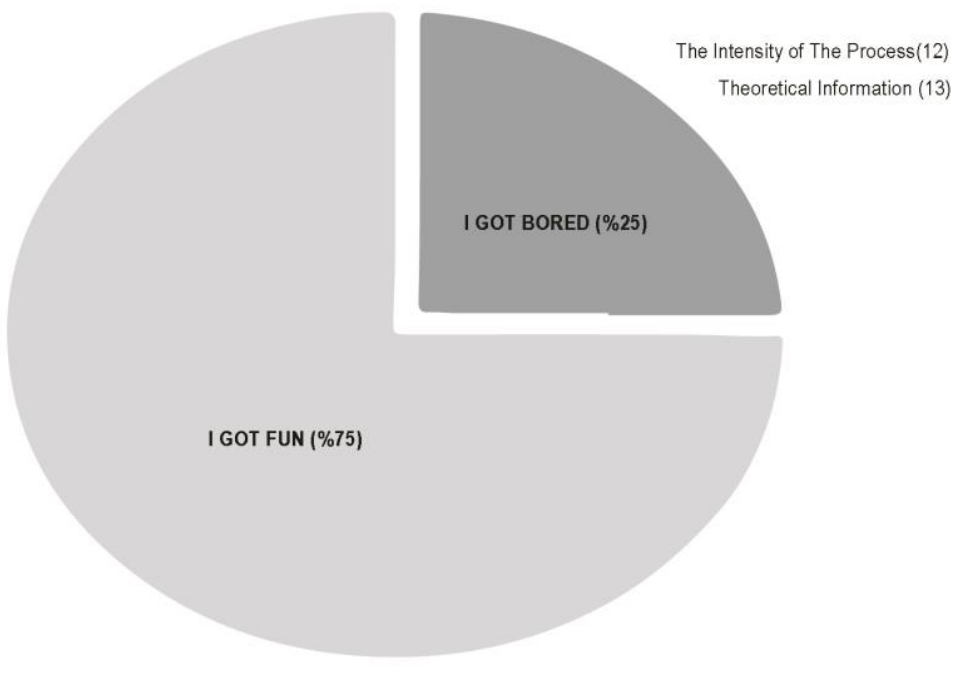

Figure 2. Participant Opinions on the State of Emotion "I Got Bored"

When Figure 2 is examined, sub-concepts and frequencies related to the theme "I got bored", which is one of the participants' state of emotions in the project process, are seen. The themes are divided into three basic titles 
which are "I got bored", "I got fun" and "I got excited".

Regarding the title "I had fun" in the project process, the participant K24 stated his or her opinion saying "The activities created during the project process were very educational and entertaining. I did not get bored with any activities or practices. I wish the project lasted a little longer", while the participant K14 commented, "When I heard that I was going to participate in the project, I thought that the process would be boring and I would get tired of ongoing activities. However, the activities were so full that I could not understand how time passed and I did not get bored in any way". And the participant K08 expressed, "There were so many beautiful things that I learned to improve myself, both during the practice and during the breaks, that I didn't even think about getting bored. Without this project, I would not have understood that plants and animals are so important in our lives. As people, I understood better how much we actually damage our environment. I will be more careful from now on " However, 25 percent of the respondents stated that they got bored. Regarding this title, the students particularly complained about the intense activities and the high number of theoretical courses. The participant K22 commented, "There was constant activity throughout the project and we didn't have enough time to relax." The participant K13 said, "The lessons before the activities were long. Especially the photography lessons took too long. I think it would be more fun if we took pictures instead of lessons. "

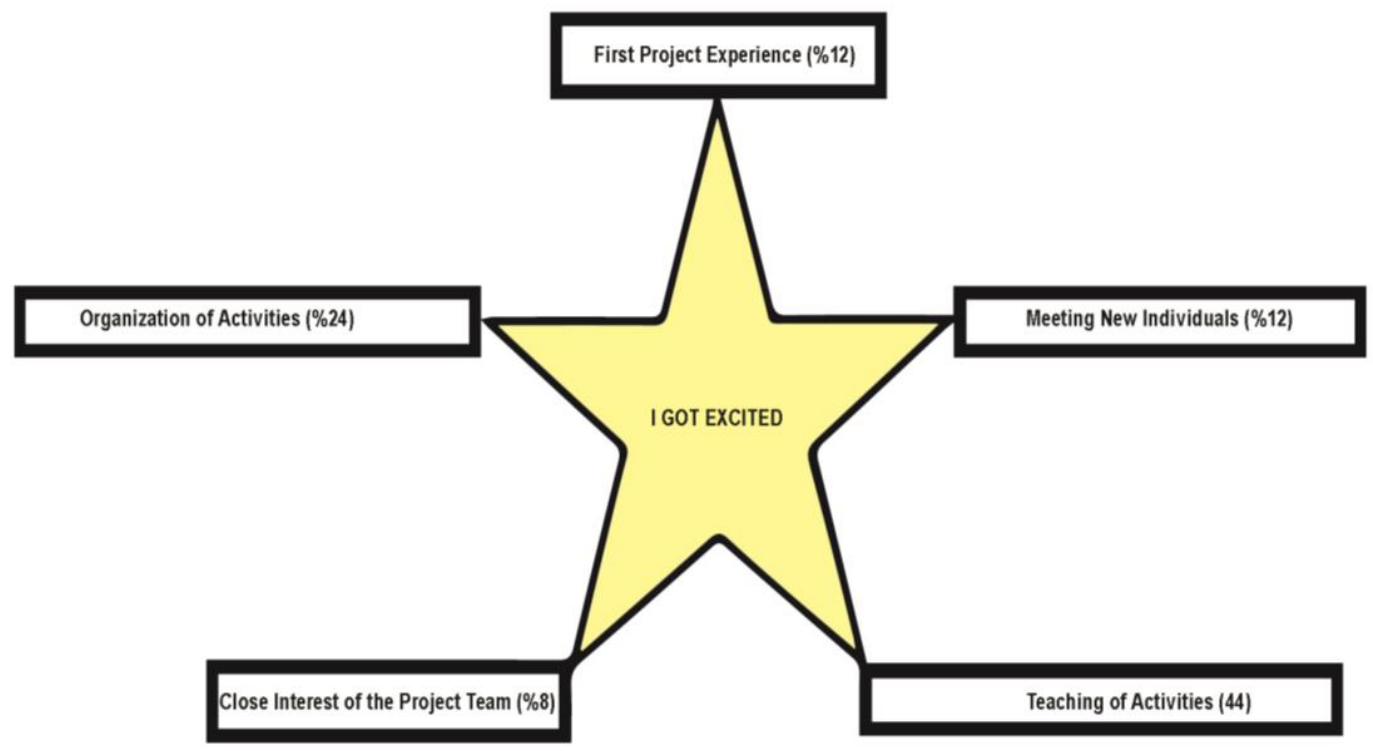

Figure 3. Participant Opinions on the State of Emotion "I Got Excited"

When Figure 3 is examined, sub-concepts and frequencies related to the theme "I got excited", which is one of the participants' state of emotions in the project process, are seen. The theme "I got excited" is divided into five basic topics, which are first project experience, meeting new individuals, instructiveness of activities, interest of project team and organization of activities.

When we look at the opinions of the participants who stated that they were excited during the project process, especially the titles organization of events and instructiveness of activities were mentioned intensively. The participant K19 commented, "I got incredibly excited that the basic components from the procurement of materials to the arrival and departure hours of the trainers had gone smoothly during the activities we carried out in this project. On my own behalf, I was afraid there would be a problem at any moment, but as the process progressed and I saw that the activities proceeded in an organized way, my excitement for the next event started to increase," while the participant K12 commented, "In our lessons, it is explained that we should be sensitive about the environment. but I did not realize that what we do affect living things so much. When I saw the injured turtles in DEKAMER, I understood better how much people actually damage their environment." whereas the participant K05 stated, "I was impressed by the fact that the activities we conducted during the project were very different from those implemented in the schools we studied. When we look at the activities, it is not difficult to observe that it was the product of a very meticulous work. However, when it comes to our ability to do is always a question mark. I am very excited to tell my classmates the information and activities I have learned and show them by doing". 


\section{Discussion, Results and Suggestions}

When the results obtained are evaluated in general, it is clearly seen that nature education program significantly contributes to both the environmental consciousness and environmental attitudes of the participants. In addition, in the evaluation made according to the sub-dimensions of the attitude scale, it is clear that the program increases students' positive attitudes towards the environment and ensures their permanence. However, no significant differences were found in the environmental perception scores of the students. These results support the idea that the project is extremely effective in increasing the environmental awareness, positive attitudes and behaviors of the students. On the other hand, the program does not have an effect on the environmental perception scores positively due to the fact that the individuals participating in the program were already positive before the training.

When the findings obtained from the "Environmental Affect Scale" three factors of the scale were identified. The effects of the activities carried out within the scope of the project on the first factor (environmental responsibility) of the scale were examined and a significant difference was found between the students' pre-test and post-test scores $(\mathrm{Z}=-2.863, \mathrm{p}<0.05)$. Considering the rank totals of the difference scores, it is seen that this difference is in favor of the positive ranks, that is, the post-test. Correspondingly, when the diaries written by the students are investigated, similar data are found. For example, the participant K13 commented as: "Before I joined the project, I thought that many things I did in my daily life were innocent things. During the nature trips and sea turtles conservation center visits in the project, I realized how wrong we actually were. For example, I learned that unconscious fishing is actually caused by the death of many turtles when not done properly". Also, the participant K22 uttered: "I was usually working alone at school. In the project, our teachers constantly asked us to work with our group of friends. When I worked this way, I realized that I learned better. Thanks to my friends, I learned that I had misbehaved before. I believe that I will do more correct things now." This result reveals that the activities carried out within the scope of the project are effective on students' environmental development, learning and individual approaches.

The effect of the activities carried out within the scope of the project on the second factor of the questionnaire (environmental sensitivity) was examined and it was determined that there was a significant difference between the pre-test and post-test scores of the students $(\mathrm{Z}=-3.928, \mathrm{p}<0.05)$. Considering the rank totals of the difference scores, it is seen that this difference is in favor of the positive ranks, that is, the post-test. At the same time, when the diaries written by the students are investigated, similar data are found. For instance, the participant K12 commented as: "In our lessons, it is explained that we should be sensitive about the environment. But I did not realize that what we do affect living things so much. When I saw the injured turtles in DEKAMER, I understood better how much people actually damage their environment". This result indicates that students' environmental awareness increased more with the activities carried out within the scope of the project.

However, when the effect of the activities carried out within the scope of the project on the third factor of the scale (environmental perception) is examined, it is identified that there is no significant difference between the pre-test and post-test scores of students $(Z=-1.402, p>0.05)$. This result shows that the activities carried out within the scope of the project are not effective enough for students' perceptions of the environment.

When the literature is analyzed, it is seen that findings similar to those mentioned above have been obtained so far. For example, Güler (2009) observed that teachers who participated in ecology-based education had significant positive changes in their attitudes towards the environment and their approach to environmental problems (Güler, 2009). Dresner and Mary (1994) found that students are more familiar with nature in summer camps, they learn more about affective awareness and ecological systems by learning environmental values. It was also witnessed significant changes in the attitudes and behaviors of groups that actively participated in environmental issues. Palmberg and Kuru (2000) observed that students exhibit more social behaviors and moral judgments thanks to having strong and empathetic relationships with nature as a result of the studies in which different environmental education programs are applied (field trips, hiking, camping and adventure activities). Moreover, they found out that the experiences in nature improve students' self-confidence, especially in the future, and they become more willing to participate in out-of-school activities.

The Environmental Behavior Scale consists of 12 items prepared as a 7-point Likert type that includes the positive behaviors of the students towards the environment. It has been determined that CLEA has a 3 -factor structure with exploratory factor analysis. In accordance with the "behavior" component by examining the items in each factor, the factors were named as "natural balance protective behavior", "social behavior" and "high level cognitive behavior". The effect of the activities carried out within the scope of the project on the first factor of the scale (natural balance protective behavior) was examined and a significant difference was found between the 
students' pre-test and post-test scores $(\mathrm{Z}=-3.742, \mathrm{p}<0.05)$. Considering the rank totals of the difference scores, it is seen that this difference is in favor of the positive ranks, that is, the post-test. Similarly, when the diaries written by the students are examined, similar data are found. To illustrate, the participant K09 said, " I was very happy that I actively participated in the sea turtle event and treated the injured animal for the first time, helping the turtles to reach the sea. It was a very important issue for me to have the chance to experience that there are many things that can be done for the plants and animals around me. I would like to participate in such applications constantly from now on.". Furthermore, K17said;"Without this project, I would not have understood that plants and animals are so important in our lives. As people, I understood better how much we actually damage our environment. I will be more careful from now on". This result demonstrates that the activities carried out within the scope of the project have a positive effect on the students' natural balance protective behaviors. Ramey- Gassert (1997) state that out of school learning environments increase willingness to learn and improve motivation for and attitudes towards learning. Such environments have positive effects on meaningful learning, both cognitively and affectively (Anderson, Lucas, \& Ginns, 2003; Griffin, 2004; Melber \& Abraham, 1999). One of the notable points observed in student views is their gratitiude for taking part in activities in an out of school, natural setting.

Likewise, a significant difference was determined between the pre-test and post-test scores of the students on the second factor of the scale (social behavior) of the activities carried out within the scope of the Project ( $\mathrm{Z}=$ $-3.939, \mathrm{p}<0.05$ ). When the rank totals of the difference scores are taken into consideration, it is seen that this difference is in favor of the positive ranks, that is, the post-test. This result reveals that the students' thoughts on social behavior improved positively with the activities carried out within the scope of the project.

Finally, when the effect of the activities carried out within the scope of the project on the third factor (high level cognitive behavior) was examined as well as its effect on the index was examined, a significant difference was found between the students' pre-test and post-test scores $(\mathrm{Z}=-4.288, \mathrm{p}<0.05)$. Should the rank totals of the difference scores are taken into consideration, it is seen that this difference is in favor of the positive ranks, that is, the post-test. At the same time, when the diaries written by the students are examined, similar data are found. For example, participant K05 stated: "I was impressed by the fact that the activities we conducted during the project were very different from those implemented in the schools we studied. When we look at the activities, it is not difficult to observe that it was the product of a very meticulous work. However, when it comes to our ability to do is always a question mark. I am very excited to tell my classmates the information and activities I have learned and show them by doing". What's more, the participant K06 said "Without this project, I would not have understood that plants and animals are so important in our lives. As people, I understood better how much we actually damage our environment. I will be more careful from now on". This result affirms that the activities carried out within the scope of the project contribute to the positive development of students' high level cognitive behavior.

When the literature is analyzed, it is found out that similar findings to those mentioned above have been obtained. For example, Bogner (1998) proposed that the 5-day outdoor program caused positive changes in students' individual behavior. Mittelstaedt, Sanker and Vanderveer (1999) found that students left the summer school with stronger positive attitudes, although they had positive attitudes towards the environment, in the summer school program, where 5-day biodiversity-related activities took place. Moreover, Eaton (2000) claimed that outdoor learning experiences are very effective in developing cognitive skills compared to classroom trainings.

Based on the results of this study, it is possible to say that such projects carried out with the support of TÜBITAK will provide an important contribution to individuals' environmental consciousness as well as their attitudes towards environment; consequently, to the environmental education in Turkey. Particularly, considering the fact that the target audience is secondary school students, it is clear that the positive attitude and consciousness will be passed on to the next generations. However, the dissemination of such projects that are both teachers and prospective teachers oriented is essential in order to reach larger audiences. Besides, the contents of the projects to be carried out are suggested to be designed and supported with the activities including active learning methods and techniques. Hereby, it will have been reached to larger audiences countrywide.

\section{Acknowledgments}

This is an TÜBITAK 4004 Nature Education and Science Schools Support Program funded research, Project Number: 118B399.

\section{References}

Anderson, D., Lucas K. B., \& Ginns, I. S. (2003). Theoretical perspectives on learning in an informal setting. Journal of Research in Science Teaching, 40(2), 177-199. https://doi.org/10.1002/tea.10071 
Akköse, E. E. (2008). Okulöncesi eğitimi fen etkinliklerinde doğa olaylarının neden sonuç ilişkilerini belirlemede yaratıcı dramanın etkililiği. Yaratıcı Drama Dergisi, 3(6), 7-24. https://doi.org/10.21612/yader.2008.008

Aslan, O., Sağır, Ş. U., \& Cansaran, A. (2008). Çevre tutum ölçeği uyarlanması ve ilköğretim öğrencilerinin çevre tutumlarının belirlenmesi. Ahmet Keleşoğlu Eğitim Fakültesi Dergisi, 25, 283-295.

Balcı, A. (2004). Sosyal Bilimlerde Araştırma; Yöntem, Teknik ve İlkeler (4.Baskı). Ankara : PagemA Yayıncılık

Birinci, O. (2013). Illkokul 3. sinıf hayat bilgisi dersine yönelik gelişstirilen doğa eğitimi etkinliklerinin ögrencilerin doğa algılarına etkisi. Yayımlanmamış Yüksek Lisans Tezi, Rize: Recep Tayyip Erdoğan üniversitesi, Sosyal Bilimler Enstitüsü.

Bogner, F. X. (1998). The influence of short-term outdoor ecology education on long-term variables of environmental perspective. Journal of Environmental Education, 29(4), 17-29. https://doi.org/10.1080/00958969809599124

Bonnet, M., \& Williams, J. (2006). Environmental education and primary children's attitudes towards nature and environment. Cambridge journal of education, 28(2), 159-174. https://doi.org/10.1080/0305764980280202

Bullock, J. R. (1994). Helping children vakue and appreciate nature. Day Care and Early Education, 21(4), 4-8. https://doi.org/10.1007/BF02361407

Burgess, J., \& Smith, M. J. (2011). Listenning to childreni perspections of nature. The Journal of Natural History Education and Experience, 5, 27-43.

Buyurgan, S., \& Buyurgan, U. (2012). Sanat eğitimi ve ögretimi. Ankara: Pegem Akademi.

Çelebi, M. (2002). Doğa eğitimi etkinliklerinin, liderlik becerilerinin ortaya çıkarılmasındaki rolü. Yayımlanmamış Yüksek Lisans Tezi, Bolu: Abant İzzet Baysal Üniversitesi Sosyal Bilimler Enstitüsü.

Çukur, D., \& Özgüner, H. (2008). Kentsel alanda çocuklara doğa bilinci kazandırmada oyun mekanı tasarımının rolü. Süleyman Demirel Üniversitesi Orman Fakültesi Dergisi, 2, 177-187.

Dilli, R. (2015). Doğa tarihi müzelerinin eğitimdeki rolü. Dumlupınar Üniversitesi Sosyal Bilimler Dergisi, 40(40).

Dresner, M., \& Gill, M. (1994). Environmental Education at Summer Nature Camp. Journal of Environmental Education, 25(3). https://doi.org/10.1080/00958964.1994.9941956

Eaton, D. (2000). Cognitive and affective learning in outdoor education. Dissertation Abstracts International Section A: Humanities and Social Sciences, 60(10-A), 3595.

Erentay, N., \& Erdoğan, M. (2012). Yirmi iki adımda doğa eğitimi. Ankara: ODTÜ Yayıncılık.

Erdoğan, M. (2011). Ekoloji temelli yaz doğa eğitimi programının ilköğretim öğrencilerinin çevreye yönelik bilgi, duyuşsal eğilimler ve sorumlu davranışlara etkisi. Kuram ve Uygulamada Eğitim Bilimleri, 11(4), 2223-2237.

Griffin, J. (2004), Research on Students and Museums: Looking more closely at the students in school groups. Science Education, 88, S59-S70. https://doi.org/10.1002/sce.20018

Güler, T. (2009). Ekoloji Temelli Bir Çevre Eğitiminin Öğretmenlerin Çevre Eğitimine Karşı Görüşlerine Etkileri (The Effects of an Ecology Based Environmental Education on Teachers" Opinions about Environmental Education). Eğitim ve Bilim (Education and Science), 34(151).

Güneş, T. ve Diğerleri. (2011). Fen ve teknoloji dersinin öğretmenler tarafindan uygulanması üzerine bir araştırma, 2. International Conference on New Trends in Education and Their Implications, Antalya: Siyasal Kitapevi ss. 1845-1853.

Hırça, N. (2012). Bilim ve Sanat Merkezi öğretmenlerinin üstün ve özel yetenekli öğrenciler için tasarlanan doğa ve bilim kampı hakkında görüşleri. Turkish Journal of Giftedness \& Education, 2, 1.

Kahyaoğlu, M. (2015). İlköğretim öğrencilerinin doğa kavramına ilişkin algılarının metaforlar yoluyla incelenmesi, Turkish Studies International Periodical for the Languages, Literature and History of Turkish or Turkic, 10(11), 831-846. https://doi.org/10.7827/TurkishStudies.8526

Kahyaoğlu, M., \& Yetişir, İ. M. (2015). Doğa kavramı ve çocukların doğadan uzaklaşmasına ilişkin fenomenografik bir çalışma. Eğitim ve Bilim Dergisi, 40(182). 159-170.

Karasar, N. (2002). Bilimsel Araştırma Yöntemi (11.Baskı). Ankara: Nobel Yayın Dağıtım. 
Karataş, A. (2011). Çevre bilincinin geliştirilmesinde doğa tarihi müzelerinin rolü. Akademik Bakış Dergisi, 27, $1-15$.

Kaska, Y., Baran, I., Ilgaz, Ç., Turkozan, O., Oz, M., \& Erdoğan, A. (2001). An estimation of the total nesting activity of sea turtles in Turkey. Proceeding of the 21th International Sea Turtle Symposium. Philedelphia-USA.

Keleş, Ö., Uzun, N., \& Varnacı, U. F. (2010). Öğretmen adaylarının çevre bilinci, çevresel tutum, düşünce ve davranışlarının doğa eğitimi projesine bağlı değişimi ve kalıcılığının değerlendirilmesi. Elektronik Sosyal Bilimler Dergisi, 9(32), 384-401.

Kırıkoglu, S. (2004). Doğa eğitimi programlarının uygulama boyutunda planlama sürecinin rolü. Yayımlanmamıs Yüksek Lisans Tezi. Bolu: Abant İzzet Baysal Üniversitesi, Sosyal Bilimler Enstitüsü.

Korfiatis, K. J. (2005). Environmental education and the science of ecology: exploration of an uneasy relationship. Environmental Education Research, 11(2). https://doi.org/10.1080/1350462042000338388

Köşker, N. (2013). İlkokul öğrencileri ve sınıf öğretmeni adaylarının doğaya ilişkin algıları ve sorumluluklarına yönelik düşünceleri. Turkish Studies - International Periodical For The Languages, Literature and History of Turkish or Turkic, 8(3), 341-355.

Kutru, Z., \& Soran, H. (2012). Üniversite öğrencilerinin doğa algıları. X. Ulusal Fen Bilimleri ve Matematik Eğitimi Kongresi.

Lutz, L., \& Musick, J. A. (1997). The biology of sea turtles. CRC Press, Inc. Newyork.

Melber, L. H., \& Abraham, L. M. (1999). Beyond the classroom: Linking with informal education. Science Activities, 36, 3-4. https://doi.org/10.1080/00368129909601027

Mittelstaedt, R., Sanker, L., \& Vanderveer, B. (1999). Impact of a weekılong experiential education program on environmental attitude and awareness. Journal of Experiential Education, 22(3), 138-148. https://doi.org/10.1177/105382599902200306

Ozaner, F. S. (2004). Türkiye'de okul dışı çevre eğitimi ne durumda? Neler yapılmalı? 5.Ulusal Ekoloji ve Çevre Kongresi, Bildiri Kitab1, 67-98. https://doi.org/10.21612/yader.2009.006

Okur-Berberoğlu, E., \& Uygun, S. (2013). Sınıf dışı eğitimin dünyadaki ve Türkiye'deki gelişiminin incelenmesi. Mersin Üniversitesi Eğitim Fakültesi Dergisi, 9(2), 32-42.

Özdemir, O. (2007). Yeni bir çevre eğitimi perspektifi: "Sürdürülebilir Gelişme Amaçlı Eğitim. Eğitim ve Bilim Dergisi, 32(145), 23-39.

Özdemir, O. (2010). Doğa deneyimine dayalı çevre eğitiminin ilköğretim öğrencilerinin çevrelerine yönelik alg1 ve davranışlarına etkisi. Pamukkale Üniversitesi Eğitim Fakültesi Dergisi, 27, 125-138.

Özdemir, P., Akfırat, N., \& Adıgüzel, Ö. (2009). Bilim ve yaratıı drama eşliğinde doğa eğitimi. Yaratıcı Drama Dergisi, 4(7), 69-78.

Palmberg, E. I., \& Kuru, J. (2000). Outdoor Activities as a Basis for Environmental Responsibility. The Journal of Environmental Education, 31(4), 32-6. https://doi.org/10.1080/00958960009598649

Ramey-Gassert, L. (1997). Learning science beyond the classroom. The elementary school journal, 97(4), 433-450. https://doi.org/10.1086/461875

Sontay, G., Gökdere, M., \& Usta, E. (2014). The Study of Scale Developing Related To The Environmental Literacy Component on the Secondary School Level. Necatibey Faculty of Education Electronic Journal of Science and Mathematics Education, 9(1), 49-80.

Stavy, R., \& Wax, N. (1989). Children's conceptions of plants as living things, Human Development, 32(2), 88-94. https://doi.org/10.1159/000276367

Şen, Ü. S. (2005). Sanat eğitiminde bilimsel araştırma yöntemlerinin kullanılması. Atatürk Üniversitesi Sosyal Bilimler Enstitüsü Dergisi, 5(1).

Şimşekli, Y. (2004). Çevre bilincinin geliştirilmesine yönelik çevre eğitimi etkinliklerine ilköğretim okullarının duyarlılı̆̆. Uludağ Üniversitesi Eğitim Fakültesi Dergisi, 17(1), 83-92.

Tanesen, Ö. T. (2008). Doğa eğitimi uygulamasındaki program ve liderlik özelliklerinin rekreasyon yönetimi açısından değerlendirilmesi (Bolu Gençlik Kampı Örneği). Yayımlanmamış Yüksek Lisans Tezi, Bolu: Abant İzzet Baysal Üniversitesi Sosyal Bilimler Enstitüsü. 
Tanrıverdi, B. (2009). Sürdürülebilir çevre eğitimi açısından ilköğretim programının değerlendirilmesi. Eğitim ve Bilim Dergisi, 34(151), 89-103.

Türkmen, L. ve Diğerleri. (2003). İlköğretim öğrencilerinin bitkiler hakkındaki alternatif kavramları, Afyon Kocatepe Üniversitesi Sosyal Bilimler Dergisi, 5(2), 53-70.

Turkozan, O., \& Kaska, Y. (2010). Turkey. In: Casale, P., \& Margaritoulis, D. (Eds.), Sea turtles in the Mediterranean: Distribution, Threats and Conservation Prioritiess (pp. 257-293). IUCN/SSC Marine Turtle Spacialist Group, Galnd; Switzerland.

Yardımc1, E. (2009). Yaz bilim kampında etkinlik temelli doğa eğitiminin ilköğretim 4. ve 5.slnıftaki çocukların doğa algılarına etkisi. Yayımlanmamış Yüksek Lisans Tezi, Bolu: Abant İzzet Baysal Üniversitesi Sosyal Bilimler Enstitüsü.

\section{Copyrights}

Copyright for this article is retained by the author(s), with first publication rights granted to the journal.

This is an open-access article distributed under the terms and conditions of the Creative Commons Attribution license (http://creativecommons.org/licenses/by/4.0/). 